\title{
Effect of Pozzolana and Lime on Expansive Soil Properties
}

\author{
Omer S. M. Hamza ${ }^{1, *}$, Magdi M. E. Zumrawi ${ }^{2}$ and Awad E. M. Mohamed ${ }^{3}$ \\ 1 PhD holder, Civil Engineering Department, Faculty of Engineering, University of Khartoum \\ 2 Deputy Dean for Academic Affairs, Faculty of Engineering, University of Khartoum \\ 3 Assistant Professor, Building and Road Research Institute, University of Khartoum \\ * Corresponding author: Omer S. M. Hamza (e-mail: omersiddigmustafa@gmail.com).
}

Article history: Received 07 March 2020, Received in revised form 4 November 2020, Accepted 11 November 2020

\begin{abstract}
This study investigates the effect of pozzolana and quick lime as stabilizer materials on expansive soil properties. Disturbed soil sample was collected from Al-Qadarif city in east of Sudan. The basic properties, swelling and strength of the soil were measured. The soil shows very weak strength and very high swelling potential. Mineralogical analysis tests were conducted to the soil using XRD tests. The soil contains significant amount of montmorillonite mineral (86\%). Laboratory tests were undertaken on soil stabilized with varying percentage of pozzolana only $(0,5,10,15,20$, and $30 \%)$ and combination of pozzolana with constant content of quick lime (5\%). Compaction, California Bearing Ratio (CBR), free swell, swell present and swelling pressure tests were performed on natural and treated soil. The pozzolana was obtained from Jebal Meidob and the lime obtained from local kilns in Kassala. The results showed that the treatment of expansive soil by combination of pozzolana and quick lime reduced soil swelling coupled with significant increase on soil strength. While the use of pozzolana only has marginal effective. It could be concluded that stabilization of expansive soil by pozzolana-lime admixture is successful.
\end{abstract}

Keywords: Expansive soil, Swelling, Pozzolana, Lime.

\section{INTRODUCTION}

Expansive soils in general have very low bearing capacity and high compressibility along with high volume changes relate to moisture conditions. They are likely lose strength further upon wetting and other physical disturbances. These soils are especially troublesome as pavement subgrades and unsuitable for construction of embankments, buildings or other light structures in their natural state. For the purpose of enhancing the engineering properties of this soil by mechanical or chemical means or both, soil stabilization generally conducted by adding stabilizing agent to the natural soil. In this process, the additive agent is typically a manufactured commercial product that enhances the soil quality only if it is added in right amounts. Such products include Portland cement, lime, fly ash, bitumen etc. Pozzolana has respectable signs as cementitious material can be used for expansive soil treatment. Pozzolana was previously used by reference [1] as cement replacing materials for use in blended cements and it was shown good results indicated that can be used as soil stabilizer.

\section{LITERATURE REVIEW}

Expansive soils covers large urban areas around the world. Sudan shows several soil types, however expansive soils are found in developed areas such as eastern and southern states. Figure 1 shows the distributions of reported expansive soil in Sudan. Expansive soils as road subgrades are undesirable due to swelling potential and weak strength. It may be desirable 
and economical to modify the properties of expansive soil by reducing expansion and increasing strength. Various techniques have been used to modify properties of expansive soils. In this study chemical stabilization was conducted for its availability, low cost and environmental friend stabilizer materials exist in Sudan.

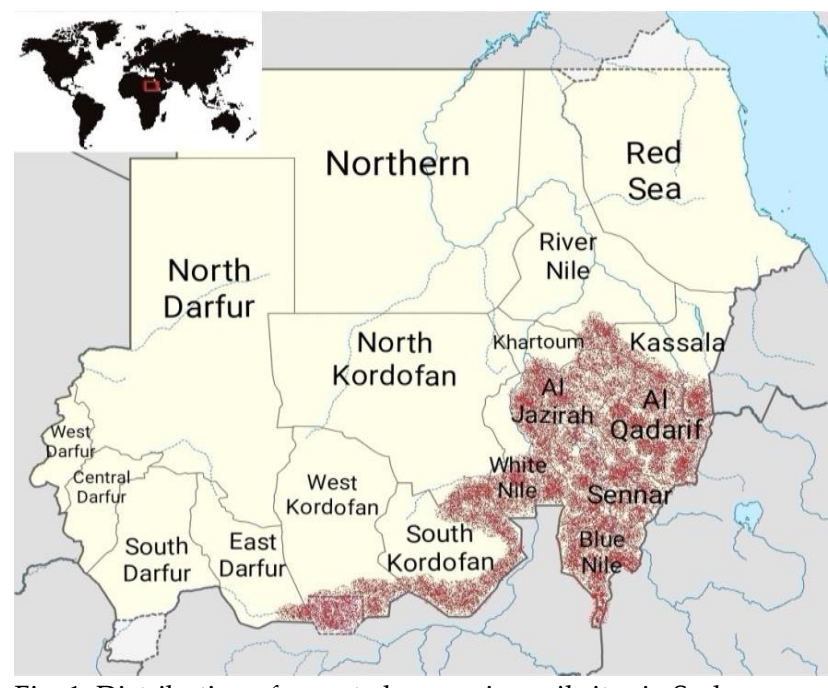

Fig. 1. Distribution of reported expansive soil sites in Sudan

Lime treatment has been used successfully in many projects to minimize swelling and improve soil plasticity and workability. Generally, from 3 to 8 percent by weight of lime is added to the soil, [2]. The primary reactions in lime reaction include cation exchange, flocculation-agglomeration, lime carbonation, and pozzolanic reaction, [3]. The strength characteristics of a lime-treated soil depend primarily on soil type, lime type, lime percentage, and curing conditions such as time and temperature. Lime is not an effective treatment for all types of soils. Some soil components such as sulfates, organics, and phosphates can cause reactions that can have serious adverse effects, [2]. Stabilization of clay soils using lime has been investigated by many researchers and has shown good results. Lime stabilization had very limited use in Sudan although the studies and research on lime stabilization of expansive clay soils showed very promising findings, [4].

\subsection{Type of Lime}

Table I lists several types of lime used as additives. Quicklime is manufactured chemically by transforming calcium carbonate $\left(\mathrm{CaCO}_{3}\right)$ into calcium oxide $(\mathrm{CaO})$ by heating. Quicklime reacts with water to form hydrated lime. Either quicklime or hydrated lime can be used as an agent for soil treatment. If quicklime is used, the first water that introduced will be used in the chemical reaction to form hydrated lime, which then reacts with the soil. Caution must be exercised when using quicklime. It can cause serious burns to skin and eyes if personnel come into contact with it. Modern spreading equipment can reduce the potential safety hazards associated with using quicklime.

Most lime used for soil treatment is "high calcium" lime, which contains $5 \%$ or less magnesium oxide or hydroxide, [5]. However, sometimes dolomitic lime, which contains 35 to $46 \%$ magnesium oxide or hydroxide can be used, [2]. Dolomitic lime can also perform well when used for soil treatment, but the magnesium fraction of the lime requires more time to react than calcium does. The type of lime that is used can influence the strength of the treated soil. Dolomitic lime generally will be more effective in increasing strength.

TABLE I: LIME MATERIALS USED IN SOIL TREATMENT [2]

\begin{tabular}{ll}
\hline \hline Type of lime & Formula \\
\hline Quick lime & $\mathrm{CaO}$ \\
Hydrated lime & $\mathrm{Ca}(\mathrm{OH})_{2}$ \\
$\begin{array}{l}\text { Dolomitic lime } \\
\text { Normal hydrated or monohydrated } \\
\text { dolomitic lime }\end{array}$ & $\mathrm{CaO} \cdot \mathrm{MgO}$ \\
$\begin{array}{l}\text { Pressure hydrated or dehydrated } \\
\text { dolomitic lime }\end{array}$ & $\left.\mathrm{Ca}(\mathrm{OH})_{2} \cdot \mathrm{MgO}\right)_{2} \cdot \mathrm{Mg}(\mathrm{OH})_{2}$ \\
\hline \hline
\end{tabular}

\subsection{Soil Factor}

Reference [2] listed the factors influencing lime reactivity of a soil include the following:

1) A soil PH greater than about 7 indicates good reactivity.

2) Organic carbon greatly retards lime-soil reactions.

3) Poorly drained soils tend to have higher lime reactivity than well drained soils.

4) Calcareous soils have good reactivity.

5) The presence of soluble sulfate salts in the soil can react with lime to cause ettrigite-induced heave.

The production of strong cementing agents can occur from reactions between lime, water, and 
aluminous or siliceous substances. The high $\mathrm{PH}$ environment created by the addition of lime increases the solubility of silica in the soils. The lime supplies a divalent calcium cation that can form calcium silicates and calcium aluminum hydrates, which can form physical bonds between particles to increase soil strength, [2].

\subsection{Curing}

Higher temperature and longer curing time improve the gain in strength for lime-treated soils. They have some influence on expansion potential as well. Reference [2] recommended a curing period of at least 10 to 14 days before heavy vehicles are allowed on the lime-treated soil.

Reference [6] reported that the lime-clay reaction takes place in two stages:

1) The first stage is cation exchange reaction whereas the sodium cations have exchange with calcium cations. This will reduce the clay particles water absorption capacity and thus reduce swelling potential.

2) The second stage happened after complete of the stage one. At this stage the lime reacts with the clay particles and produce cementitious material which produce the clay particles. The lime-clay reaction depends on the soil mineralogy. The lime is more reactive with montmorillonitic clays less than illite and far less than carollite.

\section{PREVIOUS INVESTIGATIONS}

Reference [7] studied Lime Stabilization of Tropical Soils from Sudan for Road Construction. They studied the effects of hydrated lime on the engineering properties of interest for road design and construction for three tropical clays, two highly plastic potentially expansive soils from Republic of Sudan and one red tropical "lateritic" soil from Republic of South Sudan. Effects of compaction energy on the material properties were studied. Also, effect of salinity/sodicity on plasticity and strength of lime stabilized swelling soils were studied. Their study results showed that lime efficiently reduces the plasticity of the three soils considered and that for the same increment of lime content the reduction in plasticity is higher for montmorillonitic clays compared to kaolinitic clays. Addition of lime to the three soils increased their maximum dry densities and reduced their optimum moisture content. Substantial improvement in strength and compaction characteristics of lime stabilized tropical clays could be expected on increasing the compaction effort. The permeability substantially increased on adding the optimum lime content to the three soils. Lime increased strength and stiffness of the treated soils and the amount of lime needed to improve lateritic clay soils is less than that needed to improve swelling soils. Resilient modulus test results indicated an increase in stiffness of the lime stabilized kaolinitic clay soils compared to montmorillonitic clays. The increase in salinity/ sodicity resulted in decrease of plasticity and increase in strength for the natural untreated and lime treated sodic soil tested.

Reference [8] studied the effect of hydrated lime on behavior of expansive soil as subgrade of flexible pavement structural system, by adding $2 \%, 4 \%$ and $6 \%$ of hydrated lime to an expansive soil cured within 24 hours. Their study outcomes showed that the lime provides better physical properties in term of liquid limit, plastic limit and plasticity index and shows that the lime increases the $\mathrm{CBR}$ value to $52 \%, 27 \%$, and $44 \%$ when adding $2 \%, 4 \%$, and $6 \%$ lime respectively. Also, the lime decreases swelling from $4 \%$ of untreated soil to $1.20 \%, 0.01 \%$, and $0.20 \%$ when adding $2 \%, 4 \%$, and $6 \%$ lime respectively. The design of pavement thickness shows that the adding of lime decreases the thickness from $92.5 \mathrm{~cm}$ when using untreated expansive soil as subgrade to $45 \mathrm{~cm}, 35$ $\mathrm{cm}$, and $35 \mathrm{~cm}$ when using $2 \%, 4 \%$, and $6 \%$ lime respectively in stabilization of expansive soil as subgrade. The results suggest that the lime content $6 \%$ is optimum percentage that given a highly strength, lowest swelling and small thickness of pavement.

\section{MATERIALS AND EXPREMINTS}

Laboratory tests were performed on natural expansive soil and stabilized soil with varying percentage of pozzolana only $(0,5,10,15,20$, and $30 \%)$. Then by pozzolana-lime admixture as the same percentages of pozzolana mixed with $5 \%$ quicklime as activator. Stabilizer materials were 
added to the soil to investigate their effects on soil properties.

\subsection{Materials Used}

a) Expansive soil

Expansive soil is considered to be the most problematic soil all over the world due to their swelling behavior when in contact with water and shrink on removal of water. For this study, disturbed soil sample was collected from Al-Qadarif city. Buildings and roads there have visible signs of cracks, settlements and damages due to expansive clay. Generally Al-Qadarif soils are known as high plastic clay of weak strength. The soil sample was collected from depth 0.5 to $1.0 \mathrm{~m}$ of the pit hole. The soil is often black and stiff clay. The soil was initially air dried and pulverized to pass through IS-425 Micron Sieve and then oven dried at $110^{\circ} \mathrm{C}$ before testing.

\begin{tabular}{lc} 
TABLE II: PHYSICAL PROPERTIES AND MINERAL CONTENTS OF THE SOILS \\
\hline \hline Property & Value \\
\hline Gravel (\%) & 2.8 \\
Sand (\%) & 5.0 \\
Silt (\%) & 16.3 \\
Clay (\%) & 75.9 \\
Specific gravity & 2.712 \\
Liquid limit (\%) & 80 \\
Plastic limit (\%) & 32 \\
Plasticity index (\%) & 48 \\
Free Swell Index (\%) & 205 \\
Swell percent at 1 psi (\%) & 5.3 \\
Swelling pressure (Kpa) & 240 \\
Optimum moisture content (\%) & 27.4 \\
Maximum dry density (g/cm $\left.{ }^{3}\right)$ & 1.3533 \\
CBR (\%) & 1.1 \\
Kaolinite (\%) & 12.3 \\
Illite (\%) & 1.3 \\
Montmorillonite (\%) & 86.2 \\
Chlorite (\%) & 0.2 \\
\hline \hline
\end{tabular}

The engineering properties measured for the natural soil are presented in Table II. The soil sample contains great amount of montmorillonite mineral (86\%). The more montmorillonite mineral deposited in a soil, the more volume changes exhibited. The soil sample grouped as clayey soil in accordance to the gradation analysis $(76 \%$ clay). According to the plasticity index category the soil can be classified as expansive soil. The soil demonstrated high swelling potential as free swell index is more than $200 \%$. The soil strength is very low $(\mathrm{CBR}=1.1 \%)$

\section{b) Pozzolana}

The pozzolana sample used in this study was brought from the volcanic field of Jebal Meidob in Northwest of Sudan. The volcanic field located in North Darfur with coordinates as N: $15.2606717^{\circ}$, E: $26.4276090^{\circ}$. Reference [9] reported that the volcanic field is formed by overlapping Lava flows which cover 100 by $50 \mathrm{~km}$ and emanate from 700 vents, mainly scoria cones. Lava domes, fallout and pyroclastic flow deposits are also common. The volcanic field has erupted rocks ranging from Basanite to Trachyte and rises form tectonic uplift known as Darfur dome.

The sample was grounded, sieved and then characterized in the Industrial Research and Consultancy Center in the Ministry of Industrial in Khartoum. The chemical analysis tests were performed using the international methods of analysis (IS: 1727-1967). The sample has respectable signs as cementitious material can be used for expansive soil treatment. The sample was previously used by Reference [1] as cement replacing materials for use in blended cements. The sample was shown good results indicated that can be used as soil stabilizer. The basic constituents of this pozzolana used for soil treatment is given in Table III.

TABLE III: CHEMICAL COMPOSITION OF POZZOLANA USED FOR TREATMENT

\begin{tabular}{lc}
\hline \hline Chemical composition & Percentage \\
\hline Silica $\left(\mathrm{Si} \mathrm{O}_{2}\right)$ & 49.98 \\
Aluminum $\left(\mathrm{Al}_{2} \mathrm{O}_{3}\right)$ & 20.33 \\
Ferric $\left(\mathrm{Fe}_{2} \mathrm{O}_{3}\right)$ & 0.79 \\
Calcium $(\mathrm{Ca} \mathrm{O})$ & 8.60 \\
Magnesium oxide $(\mathrm{Mg} \mathrm{O})$ & 3.47 \\
Chloride $(\mathrm{CI})$ & 0.017 \\
Sulfite $\left(\mathrm{SO}_{3}\right)$ & 0.00 \\
\hline \hline
\end{tabular}

\section{c) Lime}

The lime used in this study was quicklime, commonly known as burnt lime with the chemical formula calcium oxide $(\mathrm{CaO})$. Quicklime or calcium oxide is usually made by the thermal decomposition of limestone that contain calcium carbonate $\left(\mathrm{CaCO}_{3}\right)$ in a lime kiln of heating 
energy of nearly $1000^{\circ} \mathrm{C}$. This process known as calcination or lime burning to release a molecule of carbon dioxide $\left(\mathrm{CO}_{2}\right)$ and leaving quicklime as depicted in equation (1).

$$
\mathrm{CaCO}_{3}+\text { Heating }=\mathrm{CaO}+\mathrm{CO}_{2}
$$

Quicklime as well as hydrated lime are known for their considerably increase the bearing capacity and reduce swelling of clay-containing soils. They do this by reacting with finely divided silica and alumina to produce calcium silicates and aluminates which possess cementing properties.

The lime sample used in this study was obtained from Al-Giera lime sedimentary basin in Kassala state. Al-Giera lime sedimentary basin is located next to the eastern boundaries of Sudan towards Eritrea and lying next to Al-Gash seasonal river. The basin is about $33 \mathrm{Km}$ south of Kassala downtown. The quicklime is widely used as building material in Kassala. The lime sample used in this study satisfies the general requirements for construction purposes.

The lime sample was produced by crashing the limestone which obtained from Al-Giera lime sedimentary basin. The limestone crashed locally using crashing machines to sizes as aggregates then sieved and pulverized to smaller sizes. Then the pulverized lime subjected to nearly $1000^{\circ} \mathrm{C}$ using local lime kilns. The form of the final produced lime is powder.

\subsection{Experiments}

A laboratory testing program was conducted on expansive soil which comprises common subgrade soil in Al-Qadarif. Soil samples (natural and treated) were subjected to laboratory experiments to determine their engineering properties such as plasticity, free swell, swell percent, swelling pressure, compaction characteristics, and CBR. The tests carried out on the natural soil sample include specific gravity, sieve analysis, Consistency limits.. These tests were conducted according to the standard procedures BS 1377.

\section{RESULTS AND DISCUSSION}

The primary objective of this study is to investigate experimentally the effect of pozzolana and pozzolana-lime admixture on soil properties.
Laboratory tests were conducted on soil samples prepared by adding different percentages of pozzolana and a fixed percent of quicklime (5\%) to the expansive soil. The tests results are presented and discussed. Table IV shows the summary of tests results of the soil stabilized by pozzolana only while Table $\mathrm{V}$ shows the tests results of the soil treated with various percentages of pozzolana combined with constant $5 \%$ quicklime.

TABLE IV: THE CHARACTERISTICS OF THE SOIL TREATED WITH

\begin{tabular}{|c|c|c|c|c|c|c|}
\hline \multicolumn{7}{|c|}{ POZZOLANA } \\
\hline \multirow{2}{*}{ Property } & \multirow{2}{*}{$\begin{array}{l}\text { Natural } \\
\text { soil }\end{array}$} & $5 \%$ & $10 \%$ & $15 \%$ & $20 \%$ & $30 \%$ \\
\hline & & Pozz & Pozz & Pozz & Pozz & Pozz \\
\hline LL (\%) & 80 & 80 & 78 & 77 & 76 & 74 \\
\hline PL (\%) & 32 & 43 & 40 & 40 & 40 & 39 \\
\hline PI (\%) & 48 & 37 & 38 & 36 & 36 & 35 \\
\hline FSI $(\%)$ & 205 & 190 & 180 & 160 & 100 & 98 \\
\hline $\begin{array}{l}\text { S\% at } \\
7 \mathrm{Kpa} \mathrm{( \% )}\end{array}$ & 5.3 & 5.4 & 4.5 & 3.7 & 4.9 & 4.7 \\
\hline SP (Kpa) & 240 & 194 & 172 & 105 & 116 & 160 \\
\hline $\begin{array}{l}\text { MDD } \\
(\mathrm{g} / \mathrm{cm} 3)\end{array}$ & 1.408 & 1.385 & 1.395 & 1.392 & 1.365 & 1.376 \\
\hline OMC (\%) & 27.4 & 31.5 & 30.6 & 30.6 & 32.2 & 31.0 \\
\hline CBR (\%) & 1.1 & 1.5 & 1.4 & 1.9 & 2.5 & 1.9 \\
\hline
\end{tabular}

TABLE V: THE CHARACTERISTICS OF THE SOIL TREATED WITH POZZOLANA AND CONSTANT CONTENT OF LIME $(5 \%)$

\begin{tabular}{lllllll}
\hline \hline Property & $\begin{array}{l}\text { Natural } \\
\text { soil }\end{array}$ & $\begin{array}{l}5 \% \\
\text { Pozz }\end{array}$ & $\begin{array}{l}10 \% \\
\text { Pozz }\end{array}$ & $\begin{array}{l}15 \% \\
\text { Pozz }\end{array}$ & $\begin{array}{l}20 \% \\
\text { Pozz }\end{array}$ & $\begin{array}{l}30 \% \\
\text { Pozz }\end{array}$ \\
\hline LL (\%) & 80 & 61 & 58 & 59 & 60 & 60 \\
PL (\%) & 32 & 38 & 41 & 44 & 49 & 48 \\
PI (\%) & 48 & 23 & 18 & 14 & 10 & 12 \\
FSI (\%) & 205 & 140 & 100 & 90 & 80 & 60 \\
$\begin{array}{l}\text { S\% at } \\
\text { 7Kpa (\%) }\end{array}$ & 5.3 & 0.28 & 0.09 & 0 & 0 & 0 \\
$\begin{array}{l}\text { SP (Kpa) } \\
\text { MDD }\end{array}$ & 240 & 122 & 49 & 0 & 0 & 0 \\
$($ g/cm3) & 1.408 & 1.435 & 1.455 & 1.465 & 1.450 & 1.437 \\
OMC (\%) & 27.4 & 28.5 & 27.5 & 26 & 27 & 28 \\
CBR (\%) & 1.1 & 58.7 & 60.0 & 102.5 & 98.0 & 96.8 \\
\hline \hline
\end{tabular}

From theses Tables, it seems that using the pozzolana only as stabilizer material have marginal changes in some engineering properties of the soil such as swelling properties. The use of pozzolana and lime together as a stabilizer improved the soil properties.

\subsection{Effect on Atterberg's Limits}

Atterberg's limits of soil treated with pozzolana 
only and pozzolana combined with constant content of quicklime (5\%) are presented in Tables IV and $V$ and plotted in Figures 2 and 3 respectively. We observed from these figures that addition of pozolana only to the soil has marginal effect on soil plasticity. Addition of $20 \%$ pozzolana with $5 \%$ quicklime reduced the soil plasticity to about $80 \%$ of the initial value.

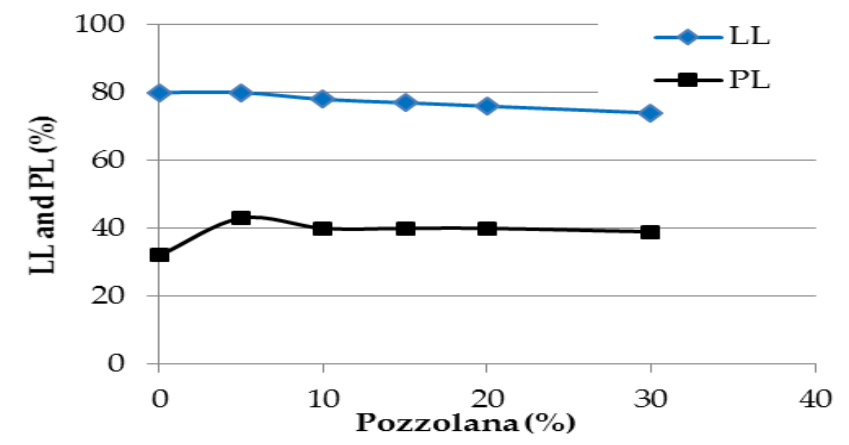

Fig. 2. Consistency limits of soil mixed with pozzolana only

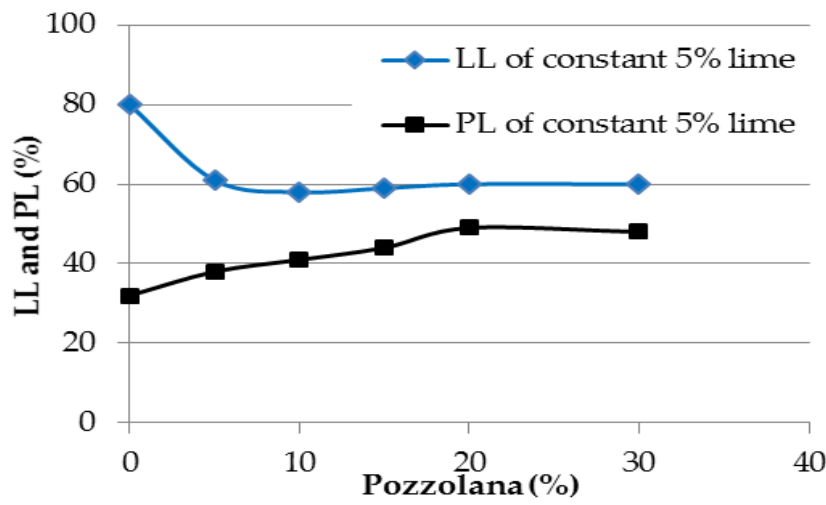

Fig. 3. Consistency limits of soil mixed with pozzolana and lime

\subsection{Effect on Free Swell Index}

Figure 4 shows effect of pozzolana and quicklime on free swell index. Addition of $20 \%$ of pozzolana alone has reduced free swell index by almost $50 \%$ of the initial value. The use of pozzolana with quicklime reduced free swell index. Adding 30\% pozzolana with $5 \%$ quicklime reduced free swell index by $70 \%$ of the initial value.

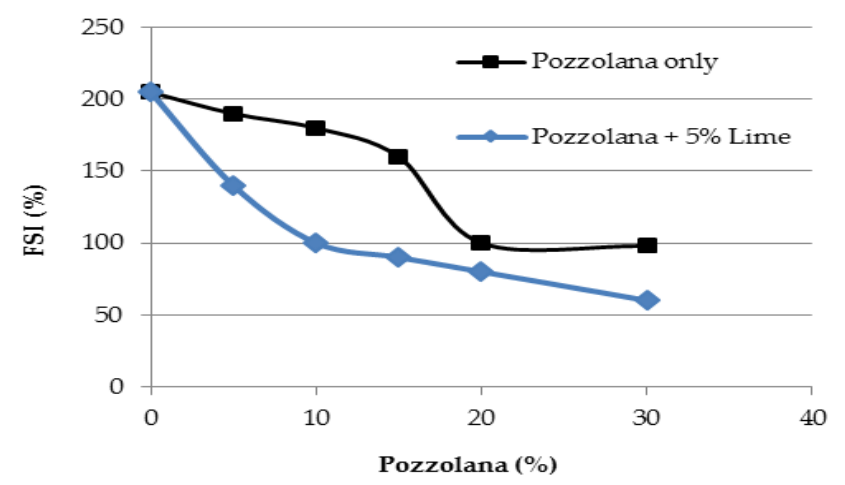

Fig. 4. Effect of soil additives on FSI

\subsection{Effect on Swell Percent}

The effect of additives on swell percent is depicted in Figure 5. It seems as shown in the figure the use of pozzolana only as soil stabilizer reduced the swell percent. However, the use of the combination of pozzolana and quicklime almost prevented soil swelling which evident the significant effect of quicklime on expansive soil treatment.

We observed that adding $15 \%$ of pozzolana only to soil reduced swell percent by $30 \%$ of the initial value. Further addition of pozzolana (20 and $30 \%$ ) resulted in increase of swell percent. But when quicklime engaged together with pozzolana free swell was remarkably reduced. Addition of $5 \%$ pozzolana and $5 \%$ quicklime to the soil reduced swell percent by $95 \%$ of the natural soil value. Further addition of pozzolana $(10 \%)$ with the constant content of quicklime (5\%) reduced swell percent by $98 \%$. More addition of pozzolana with the constant content of quicklime (5\%) completely prevented soil swelling.

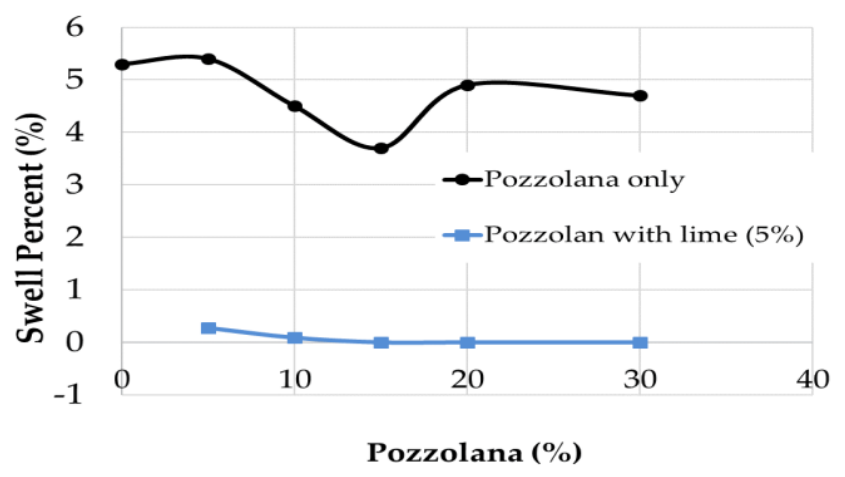

Fig. 5. Effect of soil additives on swell percent

\subsection{Effect on Swelling Pressure}

The effect of additives on swelling pressure is graphically depicted in Figure 6. We remarked that the use of up to $15 \%$ of pozzolana only reduced the swelling pressure. Beyond that an increments in swelling pressure was observed. The use of $15 \%$ of pozzolana only reduced swelling pressure by nearly $60 \%$ of the initial value. On the other hand the use of the combination of pozzolana and quicklime almost prevented swelling pressure. Addition of 5\% pozzolana with the constant content of quicklime (5\%) to the soil reduced swelling pressure by $50 \%$ of the initial value. Further addition of pozzolana 
$(10 \%)$ with the constant content of quicklime $(5 \%)$ reduced the swelling pressure by $80 \%$. Further addition of pozzolana with the quicklime $(5 \%)$ was completely prevented swelling pressure.

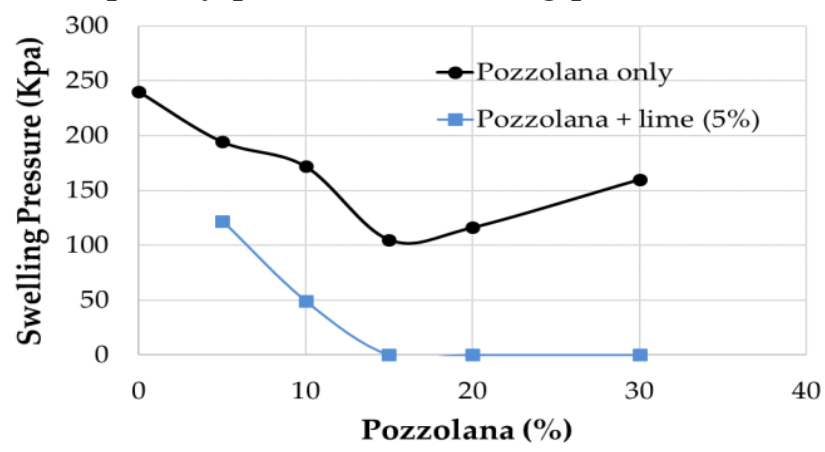

Fig. 6. Effect of soil additives on swelling pressure

\subsection{Effect on Compaction Parameters}

The variation of compaction parameters (maximum dry density and optimum water content) of the treated soil samples are graphically plotted in Figures 7 and 8. We clearly observed that the treatment of soil samples by pozzolana only has inversely effect to the soil strength, maximum dry density reduced and optimum water content increased. However, presence of quicklime was greatly improved the soil strength.

From the Figures, it can be seen that addition of $15 \%$ pozzolana combined with $5 \%$ quicklime give the maximum strength value.

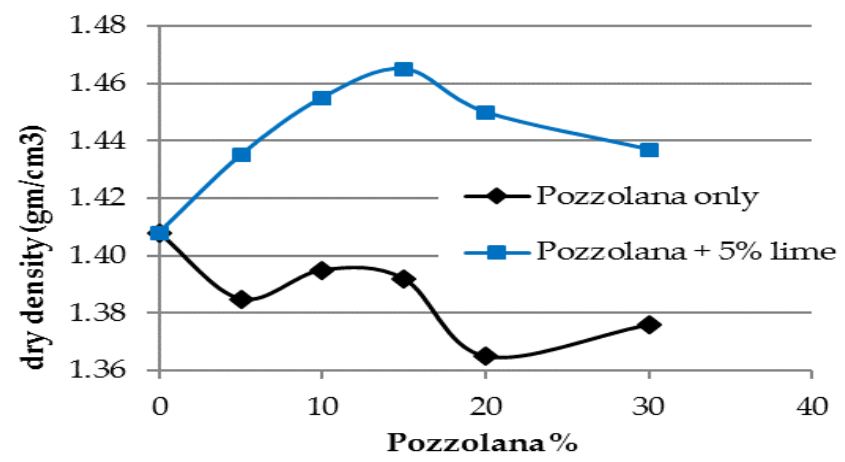

Fig. 7. Effect of additives on maximum dry density

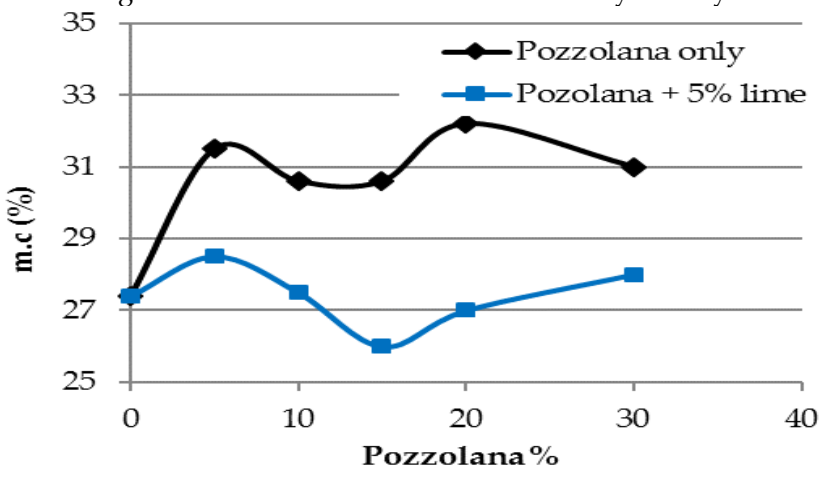

Fig. 8. Effect of additives on optimum moisture content

\subsection{Effect on CBR}

Effect of additives on CBR measured at maximum dry density and optimum moisture content is plotted in Figure 9. We observed that addition of pozzolana alone has inconsiderable effect to CBR, while presence of $5 \%$ quicklime in the soil pozzolana mixture is rapidly increased the CBR. 5\% quicklime when added to soil-pozzolana mixture increased CBR value to nearly $60 \%$. When $15 \%$ pozzolana with $5 \%$ quicklime was added to the soil, CBR value becomes almost 100 times of the original value.

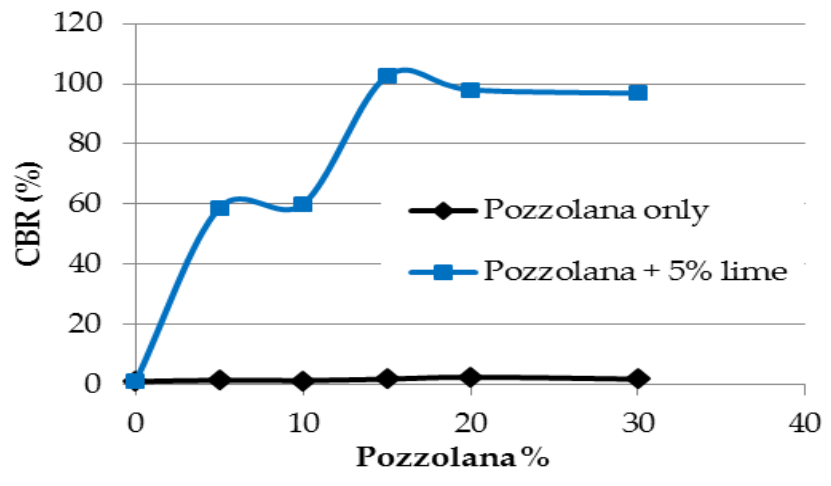

Fig. 9. Effect of additives on CBR

\section{CONCLUSION AND RECOMMENDATIONS}

Expansive soils as roads subgrade are undesirable due to swelling potential and weak strength. It may be desirable and economical to modify the properties of expansive soil by reducing expansion and increasing strength. Various techniques have been used to modify the properties of expansive soils. In this study chemical stabilization was conducted for the availability, low cost and environmental friend stabilizer materials in Sudan.

The basic properties of the soil sample was measured. Liquid limit of the soil gives $80 \%$. Plasticity index of the soil is $48 \%$. The soil has high plasticity, so it was classified as highly expansive soils. The chemical analysis test results shown that the soil contains montmorillonite mineral as $86 \%$. This indicated that the soil has high expansion potential.

The swelling characteristics of the soil was measured as, free swell index (205\%), swell percent at $1 \mathrm{psi}(5.3 \%)$, and swelling pressure (240 $\mathrm{Kpa})$. The experimental results indicated that the soil gives very low values of CBR (1.1\%). 
Two stabilizers materials were engaged in this study, pozzolana and quicklime. They were used as first, varying percentages of pozzolana alone (5, 10, 15, 20, and $30 \%$ by weight). Then, combination of pozzolana and quicklime, as constant content of quicklime (5\%) added to each percentage of pozzolana. The pozzolana was obtained from Jebal Meidob in west of Sudan, while quick lime was obtained from local kilns in Kassala in east of Sudan. The use of pozzolana alone has marginal effect on free swell and slightly reduced swell percent and swelling pressure. The free swell index was reduced by $50 \%$ when $20 \%$ pozzolana is added. However, the use of the combination of pozzolana and quicklime almost prevented soil swelling. The use of pozzolana alone has inversely effect on compaction parameters, whereas it has no effect on soil plasticity and CBR. When a constant content of quicklime (5\%) was added to soil-pozzolana mixture swelling was reduced and then a remarkable increase on strength was noticed. Addition of $15 \%$ pozzolana with $5 \%$ quicklime increased the CBR to almost 100 times of the original value. It could be concluded that the use of pozzolana-lime stabilizer to expansive soil is successful, environmental friend and more economical.

As an alternative or supplement to the design of structures or pavement on expansive soil it is recommended to alter the properties of the soil in order to strengthen the soil and reduce its expansion potential. Namely, Chemical stabilization was suggested in this study as soil treatment method and it is recommended in Sudan where expansive soil exist.

Comprehensive studies of impact of expansive soil on roads and buildings in Sudan and worldwide should be conducted.

\section{REFERENCES}

[1] Ahmedai, Mutasim A., Ibraheim, El-sharif M., Ahmed, Salih A. M., and Ahmed, Yousif H., (2018), "Characterization of Jebal Medoub Volcanic ash and Pumice as Cement Replacing Materials for Use in Blended Cements", $2^{\text {nd }}$ Conference of Civil Engineering, Sudan, University of Khartoum, PP: 36-40

[2] Nelson, John D., Chao, Kuo Chieh, Overton, Daniel D. and Nelson, Erik J., (2015), “Foundation engineering for expansive soils". John Wiley \& Sons, Inc., Hoboken, New Jersey, ISBN 978-1-118-41799-7 (pdf), USA
[3] Little, D. N., (1995), "Handbook for Stabilization of Pavement Subgrades and Base Courses with Lime", Lime Association of Texas

[4] Mohamed, A. J. and Walker, R. D., (1963), “Effect of lime, moisture and compaction on a clay soil", Highway Research Record Number 29, Highway Research Board, pp. 1-12

[5] National Lime Association (NLA), (2004), “Lime-Treated Soil Construction Manual: Lime Stabilization and Lime Modification", Bulletin 326, National Lime Association

[6] Mohammed A. M., (1983), "Effect of cement on swelling potential on Sudanese black cotton soil". M.Sc. thesis, BRRI, University of Khartoum

[7] Elsharief A. M., Elhassan A. A. M. and Mohamed A. E. M., "Lime Stabilization of Tropical Soils from Sudan for Road Construction", International Journal of Geomate, Vol. 4, pp. 533-538, 2013.

[8] Adam A., Ibrahim I., Alhardllo A.,Hadi A., and Ibrahim M., "Effect of Hydrated Lime on Behavior of Expansive Soil as Road Subgrade of Flexible Pavement Structural System", Workshop of sustainable Construction Materials, pp. 64-76, China, 2012

[9] Franz, G., Breitkreuz, C., Coyle, D., El Hur, B., Heinrich, W., Paulick, H., Pudlo, D., Smith, R., Steiner, G., (1997), "The alkaline Meidob volcanic field (Late Cenozoic, northwest Sudan", Journal of African Earth Sciences. 25 (2): 263 - 291. doi: 10.1016/S0899-5362(97)00103-6. ISSN 1464-343X

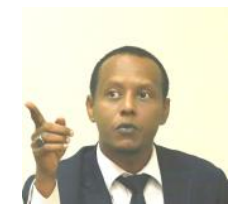

Dr. Omer S. M. Hamza was born in Kassala, Sudan, 21 July 1981. He received the B.Sc. and M.Sc. degrees in Civil Engineering from Omdurman Islamic University (2005) and University of Khartoum (2014). Now he is a Ph.D. holder (2020) from the University of Khartoum, civil engineering department. He has published two articles in 2014 and 2019 related to geotechnical engineering. He is a member of Sudanese Society for Soil Mechanics and Geotechnical Engineering.

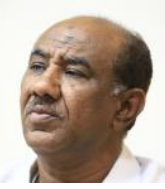

Dr. Magdi Zumrawi was born in Omdurman, Sudan, 1963. He received the B.Sc. degree in Civil Engineering and M.Sc. degree in Road Technology from University of Khartoum in 1987 and 1991, respectively. He achieved Ph.D. in Highway and Railway Engineering, Chang'An University, Xi'an, in Sept. 2000. Now he is Associate Professor in Highway Engineering. His present occupation is Dean Deputy for Academic Affairs, Faculty of Eng., Khartoum University, since Dec. 2019. He has published many articles in local and international journals and attended national and international conferences. He is a member of International Society for Soil Mechanics and Geotechnical Engineering. He is a senior member of the APCBEES.

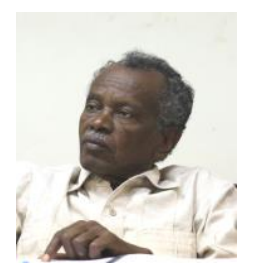

Dr. Awad E. M. Mohamed was born in Sudan. He received the B.Sc. degree in Civil Engineering and M.Sc. degree in Road Technology from University of Khartoum in 1980 and 1983, respectively. He achieved Ph.D. in Civil Engineering from the University of Strathclyde in Glasgow, in 1986. Now he is Associate Professor in Highway Engineering in Building and Road Research Institute (University of Khartoum). He is a geotechnical expert working with local and international consultant firms. 